\title{
The right to physical integrity and informed refusal: Just how far does a patient's right to refuse medical treatment go?
}

\author{
A Nienaber, ${ }^{1}$ BA (Hons), LLB, LLM, LLD; K N Bailey, ${ }^{2}$ LLB \\ 'Department of Public Law, Faculty of Law, University of Pretoria, South Africa \\ ${ }^{2}$ Bowman Gilfillan Africa Group, Sandton, South Africa
}

Corresponding author: A Nienaber (annelize.nienaber@up.ac.za)

\begin{abstract}
The article presents a legal analysis of the right to physical integrity as guaranteed by the South African Constitution, 1996, and the subsequent right of a competent adult person to refuse medical treatment under South African law. We consider whether the right to refuse treatment is an absolute right and very briefly reflect on the application of the constitutional limitations clause to this right. Instances in which patients' right to physical integrity is limited by factors, which detract from (patient) autonomy, are considered: these represent a limitation of their right to refuse medical treatment. We conclude that forced medical interventions, for the most part, are not desirable but, indeed, necessary in some narrowly defined circumstances. When a person makes a decision to refuse a medical intervention, which may seem unusual or may be perceived as irrational, it does not mean that person does not warrant the protection of the constitution and the courts. Provided that the patient makes an informed refusal while of sound mind, generally there is no reason to discredit his/her decision, difficult as it may be for others to accept. At all times the right to bodily integrity is pivotal in any health-related context and should not be lightly disregarded.
\end{abstract}

S Afr J Bioethics Law 2016;9(2):73-77. DOI:10.7196/SAJBL.2016.v9i2.472

Internationally, the human right to physical integrity and the ethical principle of autonomy and, hence, the ability of a competent adult patient to refuse medical treatment, are the subjects of frequent debate, because the limits of this right and the ethical principle, when applied in concrete situations, remain unclear. In South Africa (SA) aspects of the complex ethical and legal debate were revisited on 30 April 2015 when judgment was handed down in the North Gauteng High Court which declared it legal for Robert StranshamFord to ask a medical practitioner to help him end his life and, in doing so, upholding Robert Stransham-Ford's rights to dignity, physical integrity and his autonomy. ${ }^{[1]}$ Stransham-Ford refused medical treatment in the form of strong sedatives because he wanted to die while aware of his surroundings. ${ }^{[1]}$ The judgment is a victory, not only for those who advocate the right of competent adult persons to seek active euthanasia in specific circumstances, but also for claims of patient autonomy and patients' right to reach their own decisions regarding their medical treatment, including their right to refuse treatment.

The Stransham-Ford judgment, may indeed pave the way to legalising active euthanasia in selected cases in SA. Equally importantly, the Stransham-Ford judgment has brought to the fore the debate on the right of a competent adult person to refuse medical treatment both as an expression of his/her (human) right to physical integrity and of the ethical principle of autonomy. In light of the importance of the judgment the article presents a legal analysis of the right to physical integrity as guaranteed by the SA Constitution $1996{ }^{[2]}$ and the subsequent right to refuse medical treatment in SA law. The purpose, therefore, is not to argue for the legalisation of active euthanasia but rather to analyse the legal position pertaining to the refusal of medical treatment. We will consider whether the right to refuse treatment is an absolute right, and very briefly reflect on the application of the constitutional limitations clause to this right. Further, instances where patients' right to physical integrity is limited by factors that detract from (patient) autonomy will be considered as these represent a limitation of their right to refuse medical treatment.

It should be noted that, although we refer to the right to physical integrity as an expression of patient autonomy, we will not be examining the ethical principle of autonomy directly, as this is intended primarily as a legal analysis and not an ethical one. We realise that the two systems (law and ethics) are commensurable and cannot be separated. Further, in this context it is important to distinguish between advance directives and more (immediate) refusals of treatment. For the purposes of this article we refer to 'refusal' as including both an advance directive and an immediate refusal (unless the context specifically indicates otherwise).

\section{The refusal of medical treatment as expression of patient autonomy}

Although often mentioned internationally, and in SA, in the context of the debate regarding active euthanasia (or physician-assisted suicide), the patient's right to refuse medical treatment has not received nearly as much attention as its counterpart: the patient's right to consent to treatment. Moreover, in everyday medical practice many South Africans continue, blindly and uncritically, to follow a doctor's advice and submit to medical treatment, most probably because for the great majority of South Africans healthcare services are a luxury and usually unattainable. Consequently, patients do not consider that the treatment they are being advised to undergo may not be in their best interest, which promotes the culture of a blind acceptance of 'doctor's instructions'. Certainly, such an attitude is not conducive to an open and engaged and shared decision-making process, in a situation in which the assurance of treatment is limited to a lucky few. ${ }^{[3]}$

The principle of patient 'autonomy' is a long-standing principle of medical law: the word is derived from the Greek words autos, meaning self, and nomos, meaning to rule or govern. ${ }^{[4]}$ Thus, the 
principle of self-rule is a right bestowed on all persons; in the SA sphere by section 12(2)(b) of the Constitution of the Republic of SA. ${ }^{[2]}$ It is commonly accepted that there are two facets to the principle of patient autonomy, namely the ability to act independently from third parties and the ability to act intentionally. ${ }^{[5]}$ What it means is that a patient must be able to make a decision concerning his or her own body without undue interference, from a medical practitioner, family member, societal leader or any other source. It also presupposes that limitations, such as a lack of understanding of one's disease, treatment, prognosis or any other factor, are absent. Then, and only then, can a patient be said to act autonomously. ${ }^{[5]}$

The obligation to respect the autonomy of a patient has been concretised in the Health Professions Council of SA (HPCSA)'s General Ethical Guidelines. ${ }^{[6]}$ Thirteen 'core ethical values and standards, ${ }^{\text {[6] }}$ which medical practitioners are obliged to abide by, are listed in the Guidelines. The relevant aspects here include the obligation to respect a patient's right to self-determination and the obligation to respect human rights in general. ${ }^{[6]}$ As the right to physical integrity, including the ability to make autonomous decisions regarding one's own body, is enshrined in the Bill of Rights, ${ }^{[2]}$ medical practitioners have a general legal obligation to respect this right. The HPCSA Guidelines further, significantly, instruct medical practitioners to be tolerant of and to have respect for differing ethical, religious and moral views. ${ }^{[6]}$ This instruction re-enforces the principle of respect for autonomy, discussed above, which states that medical practitioners acknowledge that the patient has the right to have independent views.

\section{The right to physical integrity}

The right to physical integrity, as enshrined in section 12(2)(b) of the SA Constitution, is the foundation on which jurisprudence concerning patient autonomy - and the right to refuse treatment rests. Section 12(2)(b) states: 'everyone has the right to bodily and psychological integrity, which includes the right ... to security in and control over their body'. This right is supplemented in the National Health Act, $^{[7]}$ particularly in the sections dealing with informed consent (sections 6 -9), case law regarding informed consent and refusal of treatment, ethical guidelines, and various scholarly writings on the subject.

The right to physical integrity amounts essentially to a 'right to be left alone',[8] in other words, a right to make decisions concerning one's body without undue interference by others. Section 12(2)(b) of the Constitution states that everyone has the right to both security in and control over their body. These phrases confer a cluster of rights on a patient in the healthcare context. The right to security in one's body prevents unwanted disturbance of bodily integrity, as would arise in the situation where a patient is forced to undergo treatment; whereas the right to control over the body amounts to the ability to make choices regarding the body in an autonomous and independent manner. ${ }^{[8]}$ The right to control over the body would be frustrated, for instance, if a patient is coerced or unduly influenced into making a decision regarding their body, or is not given the option of making the decision at all.

The right to bodily integrity applies in all spheres of life. In a healthcare context, this right necessitates a right to give (or withhold) informed consent before any procedure is undertaken, or another process affecting one's body begins..$^{[9]}$ Herring points out that this right must not be interpreted too expansively; he presents the example that a patient has the right to choose whether to undergo treatment or not, but does not have the right to determine exactly what course of treatment is necessary. ${ }^{[10]}$ This distinction seems only logical - a patient does not demand that she/he is treated according to their own layman's knowledge rather that the expert advice of the medical practitioner.

\section{How far does this right stretch? Limiting the right to physical integrity}

It is trite law that the right to physical integrity, like other (human) rights in the Bill of Rights, may be limited (or taken away from) under certain circumstances. The limitation of rights is a necessity for a functional and effective system of government. Nevertheless, such a limitation of rights cannot be undertaken in an arbitrary manner or without regulation. Section 36 of the Constitution functions as a safeguard of individual rights as it ensures that government, or other entities which limit rights, are held accountable and are made to comply with certain standards before conduct, which limits rights, will be accepted as valid.

Section 36 of the Constitution contains the general limitation clause applicable to all rights contained in the Bill of Rights and which prescribes the permissible means of limiting rights in the Constitution. This means that every time a limitation of a person's physical integrity is contemplated or occurs, judicial intervention is possible to measure the limitation against section 36 , and so ensure compliance with the Constitution.

Specific instances of limitation of the right to physical integrity and the right to refuse treatment are discussed below.

\section{Forced medical treatment as a limitation of the right to physical integrity: How far does the right to say 'no' go?}

As has been mentioned above, the right to physical integrity, like any other right in the Constitution, may be limited. Forcing an unwilling patient to submit to medical treatment represents the ultimate limitation of that person's physical integrity. There are several possible entities or situations which may result in the limitation of a person's physical integrity; each is examined below.

\section{The state}

Thomas Hobbes is credited as the originator of the idea of a social contract between a state and its citizens; ${ }_{i}^{[1]}$ this social contract finds a fitting analogy in compulsory medical treatment authorised by the state. The state, on occasion, forces an individual or group to undergo medical treatment or procedures for a reason deemed acceptable by society. There are several reasons why a government would see fit to compel certain persons to undergo medical treatment against their will, such as in the interests of justice and public safety. Each of these is examined in more detail below.

\section{Collection of evidence: Blood samples}

In terms of the Criminal Procedure Act, ${ }^{[12]}$ a criminal court may order the taking of, inter alia, a blood sample from an accused (whose trial is pending before that Court) in order to determine the state of that accused's health ${ }^{[13]}$ or to ascertain whether the accused bears any mark, characteristic or feature. ${ }^{[13]}$ Reasonable force may be used where such accused does not co-operate, in other words, when 
the accused refuses medical treatment. ${ }^{[14]}$ The constitutionality of the use of force to obtain blood samples was challenged in S v Orrie, ${ }^{[15]}$ where the Court held, although it amounted to a limitation of the accused's bodily integrity, that drawing blood against the consent of the accused was a very limited infringement of that right. The Court also held that the limitation was justified in the circumstances, being necessary for the procurement of potential evidence and thus in the interests of justice, as well as being sanctioned by legislation (paragraph 23). ${ }^{[15]}$

Blood samples may also be required for evidence in civil matters, particularly in an instance where paternity of a child is disputed. There is no express provision authorising the drawing of the blood of a potential father in such a case; however, section 37 of the Children's $\mathrm{Act}^{\left[{ }^{[16]}\right.}$ provides that a Court may make a negative inference as to the credibility of a person refusing to submit to such a test. Although this sanction is not as stringent as in a criminal trial, it would certainly serve as a strong motivating factor in favour of the blood test being performed. It is clear, in spite of the more lenient nature of this provision, that a potential father could be forced to undergo the required tests by applying the limitations clause read with section 28(2) of the Constitution. Section 28(2) provides that the best interests of the child are of 'paramount importance' in every matter concerning that child. Therefore, provided the applicant can prove that certainty regarding paternity is in the child's best interest, a Court will likely apply section 36 and limit the potential father's right to bodily integrity so as to fulfil the requirements of the so-called 'best interests standard' set out in section 28(2).

In civil matters, when DNA evidence or other blood (or similar) tests are required, the standard limitation assessment will occur in order to determine whether, in the absence of an express statutory authorisation, an unwilling individual can be forced to undergo those tests.

\section{Collection of evidence: Other materials}

Two cases reported a year apart focussed on the issue of courtsanctioned surgery for the retrieval of evidence. These cases dealt with an accused that was shot during or shortly after the commission of a crime, leaving a bullet in his leg, which could provide crucial evidence in the case against him. In both cases, the accused refused to consent to surgery to remove the bullet.

In Minister of Safety and Security $v$ Gaqa ${ }^{[17]}$ the respondent was allegedly shot by one of two victims during the commission of a robbery-murder. The bullet lodged in the respondent's left thigh close to the femur. He was inconsistent in his explanation of the obvious wound and X-rays performed by the District Surgeon clearly showed the presence of a bullet in the tissue of the thigh (paragraphs 655A 656D). ${ }^{[17]}$ Expert witnesses indicated that the bullet was possibly the same calibre as those fired from the gun used by the victim to shoot the attacker (paragraphs 655A - 656D). ${ }^{[17]}$ Further expert testimony indicated that the procedure required to remove the bullet was relatively safe and uncomplicated (paragraphs $658 \mathrm{H} 658 \mathrm{~A}-\mathrm{C}$ ). ${ }^{[17]}$

Various provisions of the Criminal Procedure Act were relied upon by the applicants in attempting to show that the accused should be compelled to undergo surgery ${ }^{[18]}$ For the purposes of this discussion it suffices to say that the applicants relied on the provisions allowing for the use of force, first, in conducting a search, and second, in determining the condition or appearance of an individual (paragraph 658H). ${ }^{[17]}$ The applicants relied on section 205(3) of the Constitution as well, which mandates the police to investigate crimes occurring in the Republic, by stating that it was impossible for the police to investigate the matter any further without inspecting the bullet lodged in the respondent's leg. ${ }^{[2]}$

In its decision, the Court held that surgery without consent is a grave infringement of the bodily integrity, privacy and dignity of the accused (paragraph $658 \mathrm{H}$ ). ${ }^{[17]}$ It then relied on the American case of Winston v Lee, ${ }^{[19]}$ wherein the US Supreme Court stated - in much the same circumstances - that the reasonableness of forced surgery must be determined by weighing up the interests of the individual (specifically their privacy and bodily integrity) and the interests of society (the need to acquire evidence in order to prosecute crime).

Therefore, the determination of whether the surgery should be mandated by the Court becomes an exercise in the balancing of rights. In this specific case there were several factors weighing in favour of the surgery taking place, namely that it was an investigation of a very serious crime (both victims of the robbery died of their injuries); that there was no other evidence linking the accused and the crime; and that the required procedure had only minimal risks (paragraph $659 \mathrm{~B}-\mathrm{C}) .{ }^{[17]}$ The Court concluded, as a result of these factors, that the public interest, namely the investigation of serious crimes, was more important than the respondent's interest, namely protection of his bodily integrity, privacy and dignity, and ordered the respondent to consent to the surgery, failing which the Sheriff was to give consent on his behalf (paragraph 680A). ${ }^{[17]}$

The second case based on similar facts is that of Minister of Safety and Security $v$ Xaba. ${ }^{[20]}$ The Xaba judgement was handed down just ten months after the Gaqa decision. In Xaba, the accused and another allegedly hijacked a vehicle that was spotted later the same day, and the police gave chase. Shots were fired but the driver of the vehicle (the accused) escaped. An informant came forward with information that the accused had been shot in the thigh and that the bullet was believed to be lodged there. The accused was arrested and $\mathrm{X}$-rays confirmed the presence of a bullet in his thigh. He refused to consent to surgery to facilitate the removal of the bullet to be used as evidence against him (paragraphs 706F - 707G). ${ }^{[20]}$ The applicant relied on the same provisions as in Gaqa relating to the use of force in searching or ascertaining the appearance or condition of an individual (paragraph 713A). ${ }^{[2]}$

In this case the court followed a formalistic approach, basing its finding on a technical reading of the legislation and holding that the phrase - 'including the taking of a blood sample' in section 37 of the Criminal Procedure Act - showed the legislature's intention that taking a blood sample was the only medical procedure allowed in terms of this section. Surgery, such as that required to remove the bullet from the accused's leg, was not justified by section 37 (paragraph 714D - F).[20] The Court further held, in the absence of a supplied definition, that the word 'search' in section 27 had to be given its ordinary meaning, which does not include surgery or other medical procedures (paragraph 713A).[20] The court refused to allow the surgery to go ahead (paragraph 715B).[20]

In our opinion, the Court in Gaqa followed the more desirable approach to this problem, as it focused on balancing rights and interests. Although the technical reading of legislation, certainly, remains a vital function of the judiciary, the Xaba decision passed over a valuable opportunity to settle an area of human rights law. Judge Desai, in handing down judgement in Gaqa, applied clearly and concisely the provisions relating to the limitation of rights, whereas 
Acting Judge Southwood (as he then was) appears to have neglected to consider the impact of his judgement on the interests of the community.

\section{Compulsory HIV testing of alleged sexual offenders}

In terms of section 30 of the Criminal Law (Sexual Offences and Related Matters) Amendment Act ${ }^{[2]]}$ the victim of a sexual offence (or another interested person) may apply within 90 days of the offence to a Magistrate's Court, with jurisdiction to compel the alleged offender to undergo HIV testing and to allow the results of such test to be disclosed to the victim. This application must be in writing, setting out the alleged sexual offence, the identity of the alleged offender, the fact that the matter had been reported within 72 hours and the possible exposure of the victim to HIV, according to section 30(2)(a).[21]

The consent of the alleged offender is not required despite the fact that this provision represents an infringement of his dignity, privacy and bodily integrity. The Act goes so far as to state in section 38(2) that an alleged offender who refuses to consent to the taking of samples is guilty of an offence punishable by a fine or imprisonment of not more than 3 years. ${ }^{[2]]}$ While this is not an express statutory authorisation for forced treatment, the possibility of 3 years' imprisonment is a weighty factor coercing an accused to submit to the procedure. ${ }^{[22]}$

\section{Serious public health threats}

One of the more settled aspects of the jurisprudence related to forced treatment is treatment without consent in the face of an epidemic, such as extreme drug-resistant tuberculosis (XDR-TB) or the recent Ebola outbreak. Section 7(1)(d) of the National Health Act details circumstances in which treatment may be administered without the consent of the patient, including a case where a failure to treat the patient (or group of patients) would lead to a serious public health or safety risk. This provision was applied in the context of XDR-TB, in the case of Minister of Health v Goliath. ${ }^{[23]}$ In this case, the respondents had all been diagnosed with XDR-TB, which was resistant to 'first-line drugs' and to certain other drugs. They were all contagious and all had failed to comply with the voluntary treatment regimen prescribed for them (paragraphs $16-17$ ). ${ }^{[23]}$ As a result, the Minister of Health applied for an order compelling the surviving respondents (two of the original four respondents had died) to be detained in a specialist tuberculosis hospital to receive treatment (paragraphs 5 - 6). ${ }^{[23]}$

The respondents, in turn, claimed that the detention represented a violation of their rights in terms of section 12 of the Constitution, including their rights to freedom and security of the person and to bodily integrity (paragraph 14). ${ }^{[23]}$ The court considered various factors, including the Minister of Health's duty to prevent and control the spread of communicable diseases; that the respondents were capable of spreading the disease but had failed to adhere to the voluntary programme; and the toxicity and associated side-effects of the drugs necessary to treat XDR-TB (paragraph 27). ${ }^{[23]}$ Judge Griesel ruled, based on these considerations, that the detention and treatment of the respondents, although a breach of their section 12 rights, were both necessary and mandated by section $7(1)(d)$ of the National Health Act because of the public interest. ${ }^{[23]}$

The Goliath judgement received academic support: Carstens writes that the effect of the decision, specifically within the spectrum of the tuberculosis epidemic in $\mathrm{SA}$, is that considerations of public health trump the bodily integrity of individual patients. ${ }^{[24]}$

Based on the decision in Goliath it appears, if a medical intervention is necessary to protect broader society, that the rights of an individual patient are not grounds for the refusal of treatment. The patient may be forced to undergo treatment against their express wishes, and, as has been explained above, rights may be limited where such limitation serves an important purpose.

\section{Maintenance claims}

A duty of maintenance exists both between spouses (and in some cases former spouses) and between parent and child. ${ }^{[25]}$ If a parent or spouse, as the case may be, is unable to fulfil this duty, the inability must be tangible and must not be due to that person's failure to recognise their full earning potential. ${ }^{[26]}$ This means, if a person elects not to undergo certain medical treatment to the detriment of their earning capacity, that they could possibly be in breach of their duty to provide maintenance. Therefore, again, a rights-limitation investigation will have to occur - the child's (or spouse's) right to maintenance will have to be weighed against the right of the other party to bodily integrity.

Regarding the maintenance of a spouse or former spouse, it is unlikely that the courts will force a person to undergo treatment against their wishes in order to maintain a healthy and employable adult. However, the position is somewhat more clouded with regard to children. Section 28(2) of the Constitution provides that the best interests of the child are of 'paramount importance' in every matter involving the child. This provision, coupled with the Constitutional right to maintenance, ${ }^{[2]}$ declares a more significant purpose to the potential limitation of the parent's right to bodily integrity. Ultimately, every case will have to be determined on the circumstances: facts such as whether the other parent can provide maintenance, whether the child is old enough to work and to contribute to her own maintenance and the dangers and risks of the treatment required by the parent.

\section{Patient's employer}

Medical incapacity is potentially fair grounds for dismissal from employment: ${ }^{[27]}$ in some circumstances it may lead to the automatic termination of the employment relationship as a result of supervening impossibility of performance. ${ }^{[27]}$ An employer, upon discovering the medical incapacity of the employee, has an obligation to conduct an investigation into whether there exists an alternative post for that employee, or whether the employee's existing duties may be modified to compensate for the medical condition or disability of the employee. ${ }^{[28]}$ In these circumstances, an employer is entitled to request an employee to undergo a medical examination but may not compel her to do so. ${ }^{[27]}$ This, then, is not a true case of forced medical treatment.

It should be noted that the right to bodily integrity includes a right to make decisions concerning reproduction. ${ }^{[2]}$ This specific facet of the right to bodily integrity is given effect to by section 187(1)(e) of the Labour Relations Act, ${ }^{[29]}$ which provides that an employee may not be dismissed as a result of her pregnancy or intended pregnancy. It has been submitted that this section indicates the legislature's intention that the employee's bodily integrity be more stringently protected than the employer's interests. ${ }^{[2]]}$ 
It would appear from the prohibition in section 187 that an employee may never be forced to undergo a medical intervention. The prospect of becoming unemployed, however, plays a significant role in the employee's decision whether to undergo treatment.

\section{Medical practitioners}

In Castell v De Greef, the Court confirmed that beneficence does not constitute a legitimate ground to force a patient to undergo treatment. ${ }^{[30]}$ In light of quantitative research recently carried out, indicating that over $50 \%$ of medical practitioners admit to treating patients without consent based on the assumption that they would have consented, it is doubtful whether scholarly and judicial opinion has, in fact, filtered down into practice. ${ }^{[3]}$ This regrettable position somewhat muddies what should be a clear-cut distinction between autonomy and beneficence and is potentially indicative of the fact that an authoritarian attitude is alive and well among medical practitioners.

The above instances in which forced treatment was considered, as diverse as they are, have one thing in common: they serve to indicate that the right to bodily integrity is a central consideration and, in the majority of the cases, the right to bodily integrity cannot be limited. It appears that it is only in the case of the state that forced treatment is accepted, and even then there remain uncertainties and contentious aspects. It is perhaps Hobbes's theory of the social contract which best explains this phenomenon: individuals barter away some of their rights in return for protection and the regulation of violence by the government entity, in essence entering into a contract with society. Therefore, if one commits a crime by violating the terms of the contract, one is punished - it is a necessary step in working towards punishment that the crime must be investigated, which requires evidence to be obtained by various means, including blood tests and surgery. In addition, in ensuring the protection of the interest of others, certain individuals may be required to endure the limitation of their rights. This situation can arise, as indicated above, through forced treatment for a communicable and deadly disease, HIV tests to protect and empower the victims of rape and other sexual offences and DNA tests to determine the paternity of children.

\section{Conclusion}

Forced treatment as opposed to the right to physical integrity (and the ethical duty of respect for autonomy) captures an ageold conflict for medical practitioners: to treat the patient or to respect their wishes regardless of the negative consequences that their choice may have on their health. Control by the state, medical practitioners, family or others should be allowed only in the most limited of circumstances. It should be the norm that patients' decisions to refuse treatment stand, unless the interests of justice or the community permit otherwise.

We opened the discussion with reference to the Stransham-Ford judgment which, in our view, highlights the medical practitioner's first and foremost ethical duty and legal obligation to respect the autonomy and physical integrity of their patient: not only in not compelling that patient to undergo medical interventions when they decide rather to die with dignity, but also in not coercing a patient to undergo other medical interventions against their wishes.
Uncertainty and reticence are the prevailing features in any discussion of forced medical interventions. It seems to be universally understood that forced medical interventions, for the most part, are not desirable but, indeed, necessary in some circumstances. The fact that a person makes a decision to refuse a medical intervention, a choice which is unusual or may be perceived as irrational does not mean that person does not warrant the protection of the Constitution and the courts. ${ }^{\left[{ }^{[1]}\right.}$ The rights in the Bill of Rights apply to everyone, ${ }^{[2]}$ regardless of how odd or abnormal their decisions may appear to a third party. Therefore, when a patient refuses treatment it is not the role of the medical practitioner or anyone else to try to convince them otherwise, or to disregard that decision. Provided that the patient makes an informed refusal while of sound mind generally there is no reason to discredit their decision, as difficult as it may be to accept. At all times the right to bodily integrity is pivotal in any health-related context and should not be lightly disregarded.

\section{References}

1. Stransham-Ford v Minister of Justice and Correctional Services and Others 2015 (4) SA 50 (GP).

2. South Africa. Constitution of the Republic of South Africa. 1996.

3. Chima SC. Evaluating the quality of informed consent and contemporary clinical practices by medical doctors in South Africa: An empirical study. BMC Med Ethics 2013;14(Suppl 1):1-9. DOI:10.1186/1472-6939-14-S1-S3

4. Childress JF, Beauchamp TL. Principles of Biomedical Ethics. Oxford: Oxford University Press, 2009:12-13.

5. Childress JF, Beauchamp TL. Principles of Biomedical Ethics. Oxford: Oxford University Press, 2009:99-100.

6. Health Professions Council of South Africa. Guidelines for good practice in the health care professions. Booklet 1. General Ethical Guidelines for the Health Care Professions. Pretoria: HPCSA, 2008:2

7. South Africa. National Health Act No. 61 of 2003.

8. Currie I, De Waal J. The Bill of Rights Handbook. Cape Town: Juta, 2005:287.

9. Carstens PA, Pearmain D. Foundational Principles of South African Medical Law. Durban: Butterworths LexisNexis, 2007:30.

10. Herring J. Medical Law and Ethics. Oxford: Oxford University Press, 2010:21.

11. Friend C. Social Contract Theory. USA: The Internet Encyclopedia of Philosophy, 2004. http://www.iep.utm.edu/soc-cont/\#SH2a (accessed 18 August 2015).

12. South Africa. Criminal Procedure Act No. 51 of 1977.

13. South Africa. Section 37(3)(a)-(b), Criminal Procedure Act No. 51, of 1977.

14. Du Toit E, de Jager FJ, Paizes A, et al. Commentary on the Criminal Procedure Act. Cape Town: Juta, 2015:3-49.

15. S v Orrie 2004 SACR 162 (C)

16. South Africa. Children's Act No. 38 of 2005.

17. Minister of Safety and Security v Gaqa 2002 (1) SACR 654 (C)

18. South Africa. Sections 27, 37, Criminal Procedure Act No. 51 of 1977.

19. Winston $v$ Lee 470 US 7531985.

20. Minister of Safety and Security v Xaba 2003 (2) SA 703 (D).

21. South Africa. Criminal Law (Sexual Offences and Related Matters) Amendment Act No. 32 of 2007.

22. McQuoid-Mason D. Compulsory HIV testing of alleged sexual offenders. S Afr Med J 2009;99(1):26-28.

23. Minister of Health v Goliath 2009 (2) SA 248 (C).

24. Carstens $P$. The involuntary detention and isolation of patients infected with extreme resistant tuberculosis (XDR-TB): Implications for public health, human rights and informed consent. Obiter 2009;30(2):420-427.

25. Van Schalkwyk LN. General Principles of the Family Law. Cape Town: Juta, 2011:167

26. Mgumane v Setemane 1998 (2) SA 247 (Tk) Paragraphs 252B - D

27. Van Niekerk A. Law@work. Durban: LexisNexis, 2012;251,283-287.

28. NEHAWU obo Lucas v Department of Health, Western Cape 2005 (25) ILJ 209.

29. South Africa. Labour Relations Act No. 66 of 1995.

30. Carstens PA, Pearmain D. Foundational Principles of South African Medical Law. Durban: Butterworths LexisNexis, 2007:892.

31. Karels MG, Oosthuizen H. Dying to starve: A comparative analysis of legal aspects relating to consent in force-feeding of both minor and adult anorexic patients. J Juridical Sci 2010;35:70-93. 